\title{
Students' Participation in Decision-Making on School Fees Matters as a Factor in Goal Achievement in Universities.
}

\author{
F. U. Okorie (Ph.D) \\ Department of Science Education, Michael Okpara University of Agriculture, Umudike. P.M.B. 7267, Umuahia, \\ Abia State, Nigeria.
}

\begin{abstract}
This paper reveals how students' union executives and principal officers of the universities in the South Eastern States of Nigeria perceive the participation of students in decision-making on school fees matters as a factor in goal achievement. The study was a descriptive survey. The population was made up of 36 Principal Officers and 88 Students' Union Executives from nine universities in the study area. Sampling was purposive as all members of the population were used for the study. A researcher-made questionnaire was used for data collection. Results revealed calculated chi-square values of 20.12 and 34.56 respectively, as compared to tabulated chi-square value of 9.24 for 5 degrees of freedom at 0.05 level of significance. However, the frequency counts and percentages of pooled responses of Principal Officers and Students' Union Executives are at variance to each other: while the principal officers disagreed with a percentage of $94.44 \%$, that of the students' union executives was $22.73 \%$. Thus, the disagreement between the two groups could have been the source of conflict which has affected goal achievement. It is recommended among others, that university management should invite the students' leaders prior to the decision-making stage and seek their opinions first before concluding their decisions on new amount of fee to be paid.
\end{abstract}

Key words: Decision-making, students' participation, school fees, goal achievement.

\section{Introduction}

The upward review of school fees has always led to crises in universities and other tertiary institutions in the South Eastern States of Nigeria. Students have always agitated that the increase of fees is astronomical and so resorted to protests and unwholesome destruction of school facilities. The participation of students in decision-making on this aspect (school fees) is sina qua non to the attainment of peace and sustainable academic goal achievement in federal and state universities in Nigeria.

Tertiary institutions such as universities in developing nations and in Nigeria in particular have witnessed series of students' unrests that culminate to temporary shutting down of schools and its academic activities (Okorie, 2012) Most times, the reason being that of frequent increase in school fees by the school management who hardly involve the student leaders during the decision-making stage. This has brought conflicts between the students and the institutions' management (Babalola and Adedeji, 2003; Ojo, 1997). These references affirm that students engage in protests against policies and actions which they consider to be neither in their own interests nor good for the growth and development of their institutions, especially when they did not participate in such decision-making. Some argue that the issue of economic meltdown which seem to have reduced the allocation of resources to affected tertiary institutions may not be far from being the reason behind such constant upward reviews of school fees. Uyanga (1989) posited that students are capable of sabotaging the efforts of their school authorities if they are alienated completely from decisions that directly affect them, no matter how they are democratically administered. Researching on Students-Authority Conflict in Nigerian Universities, Adebayo (2009) revealed that conflict is inevitable in both Federal and State universities and that students' non involvement in decision-making was identified as the major cause of student-authority conflict. This calls for the need to adopt participative system 4 of Likert (1971), whereby subordinates develop trust, loyalty, friendliness, warmth and commitment to the policies of their institutions due to the supportive role and open administration of their school authorities. This, no doubt, would enhance peaceful academic atmosphere that encourages goal achievement. If students and staff are involved in making decisions about salient issues concerning their lives they are likely to identify with outcomes of such processes. Colleges with institutionalized participation experience less staff/student related administrative problems (Boom, 2005; Obondoh, 2000).

Students at tertiary level of institutions seem to be at such assertive stage of development whereby they want to be part of decisions on issues that concern them. This agrees with Okemakinde and Babalola (2003) who reiterate that the present generation of university students are products of modern social system, which have little recognition for the virtues being upheld by older generations. Therefore, the paternalistic attitude that views university students as wards, who do not deserve to be consulted, is being seriously challenged. Cole (2005) explains that democratic or shared decision-making creates conducive organizational climate and that it 
makes room for developing in members the requisite competences, raises the participants' morale and inculcates feelings of belongingness.

\section{Design of Study}

\section{Research Method}

The design of study is a descriptive survey in which data collection involves a target population from nine Universities. This design is considered appropriate because the events being studied have already taken place. That means students' involvement or non-involvement in decision-making in those institutions is an already existing situation.

\section{Area of Study}

The study was carried out in nine Universities in the South Eastern States of Nigeria comprising of Abia, Imo, Anambra, Enugu and Ebonye States.

\section{Population of Study}

The population of study consists of all 138 Principal officers and students' union executives of the nine universities in the south eastern part of Nigeria. This is made up of 49 Principal Officers and 89 Students' Union Executives in both State and Federal Universities in South Eastern States of Nigeria. The distribution of the target population and Universities involved are shown in table 1 below.

Table 1: Population of study

\begin{tabular}{|c|c|c|c|c|c|c|c|c|c|}
\hline S/No. & State & Federal Universities & 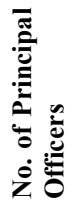 & 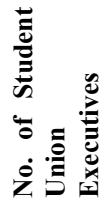 & Total & State Universities & 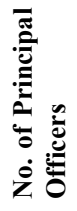 & 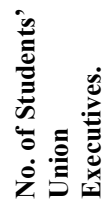 & Total \\
\hline 1. & Abia & $\begin{array}{lr}\text { Michael } & \text { Okpara } \\
\text { University } & \text { of } \\
\text { Agriculture } & \text { Umudike }\end{array}$ & 5 & 9 & 14 & $\begin{array}{l}\text { Abia State } \\
\text { University, Uturu }\end{array}$ & 6 & 10 & 16 \\
\hline 2. & Anambra & $\begin{array}{l}\text { Nnamdi Azikiwe } \\
\text { University Awka }\end{array}$ & 6 & 9 & 15 & $\begin{array}{l}\text { Anambra State } \\
\text { University of Science } \\
\text { and Technology, Uli }\end{array}$ & 5 & 10 & 15 \\
\hline 3. & Ebonyi & - & - & - & - & $\begin{array}{lr}\text { Ebonyi } & \text { State } \\
\text { University, Abakaliki }\end{array}$ & 5 & 11 & 16 \\
\hline Total & 5 & 4 & 23 & 37 & 60 & 5 & 26 & 52 & 78 \\
\hline
\end{tabular}

Source: Data collected from the Institutions

\section{Sample and Sampling Techniques}

A purposive sampling technique was used consisting of the entire 138 Principal Officers and Students' Union Executives of the Universities in the South Eastern States of Nigeria. The choice of using the entire population is informed by the population being relatively small.

\section{Instrument for data collection}

The instrument for data collection was a researcher-made questionnaire called students' participation in decision-making and goal achievement questionnaire (SPIDAQAQ) used for two groups of respondentsPrincipal Officers and Students' Union Executives. The questionnaire was divided into two sections A and B.

Section A focused on bio-data comprising of name of institution, proprietorship of the institution and status' of the respondents. Section B focused on students' participation in decision-making with participation in school fees matters as a subset.

The response to the statements were a modified four-point rating scale of Strongly Agree (SA) $=4$ points, Agree $(A)=3$ points, Disagree $(D)=2$ points and Strongly Disagree $(S D)=1$ point. All responses under Agree and Strongly Agree were collated and taken as "Agree" while responses under Disagree and Strongly Disagree were collated and taken as "Disagree"

\section{Validation of the Instrument}


The face and content validity were determined by giving the questionnaire items to experts in measurements and evaluation. Their inputs were requested in checking the relevance, correctness and any ambiguity of items to ensure that the questionnaire items elicited the required responses. Their contributions were used to review and modify the questionnaire items, resulting in 6 items on students' participation in school fees matters.

\section{Reliability of Instrument}

To ascertain the reliability of the instrument, the validated items were subjected to a pilot test. This was done by administering the instrument on a total of 15 Students' Union Executives and 6 Principal Officers of University of Uyo, Akwa Ibom State, as they were not part of the main study.

A test-retest method of two weeks interval was used to determine the reliability of the questionnaire items over time. The scores from the two tests were analyzed using Pearson Product Moment Correlation Coefficient Statistic. This yielded a reliability coefficient of 0.64 which was considered adequate for the study.

\section{Administration of the Instrument}

The questionnaire for the Principal Officers were personally administered by the researcher while those of the Students' Union Executives were administered by 9 research assistants who were properly briefed on retrieval. The administration and retrieval of the questionnaires were accomplished within one month with about $90 \%$ return rate.

\section{Results and Discussion}

Tables 2a, $2 b$ and bar chart of figure I show the perceptions of Principal Officers and Students' Union Executives on students participation in decision-making on school fees matters as a factor in goal achievement. While 12 pooled responses from Principal Officers representing 5.56\% agreed, 204, pooled responses, representing 94.44\% disagreed. The Students' Union Executives agreed with a pooled responses of 408 , representing $77.27 \%$ while those who disagreed have a pooled responses of 120 , representing $22.73 \%$.

The perception of the Principal Officers may stem from the impression that students as trainees are inexperienced to make logical contributions during decision-making as well as the fact that they ( students ) may not know the implications of their suggestions in sensitive matters such as school fees. (kaye, 1970; Enoh el al, 1987; Wyn, 1979.)

On the other hand, students' agitation for participation in decision-making may arise from their understanding of students' rights in line with current global trend (especially in developed countries) whereby students are regarded as competent, active and constructive partners in school administration (Regents of the University of Michigan, 2008; Dimritri, 2005; Thierry, 2011; Rither et al 2011)

Table 2: Perceptions of Principal Officers and Students' Union Executives on Students' Participation in Decision-Making on School Fees Matters and Goal Achievement.

\begin{tabular}{|c|c|c|c|c|c|c|c|}
\hline \multirow{3}{*}{$\mathbf{S} / \mathbf{N}$} & \multicolumn{7}{|l|}{$\begin{array}{lc}\text { Table 2a } & \text { Principal Officers. }\end{array}$} \\
\hline & \multirow[t]{2}{*}{ Questionnaire Items } & \multicolumn{2}{|c|}{ Agree } & \multicolumn{2}{|c|}{ Disagree } & \multicolumn{2}{|c|}{ Total } \\
\hline & & No & $\%$ & No & $\%$ & No & $\%$ \\
\hline 1 & $\begin{array}{l}\text { Students' involvement in decision-making on the amount of fees to pay } \\
\text { is a factor in goal achievement. }\end{array}$ & 6 & 16.7 & 30 & 83.3 & 36 & 100 \\
\hline 2 & $\begin{array}{l}\text { Students' involvement in decision-making on the mode of school fees } \\
\text { payment will bring about goal achievement. }\end{array}$ & 1 & 2.8 & 35 & 97.2 & 36 & 100 \\
\hline 3 & $\begin{array}{l}\text { Students' involvement in making decisions on the time frame for } \\
\text { payment of school fees will contribute to goal achievement. }\end{array}$ & 0 & 0 & 36 & 100 & 36 & 100 \\
\hline 4 & $\begin{array}{l}\text { Students' participation in making decisions on hostel accommodation } \\
\text { fees will facilitate goal achievement. }\end{array}$ & 5 & 13.9 & 31 & 86.1 & 36 & 100 \\
\hline 5 & $\begin{array}{l}\text { Students' involvement in taking decisions on the choice of banks for } \\
\text { payment of school fees will contribute to goal achievement. }\end{array}$ & 0 & 0 & 36 & 100 & 36 & 100 \\
\hline 6 & $\begin{array}{l}\text { Students' participation in making decisions on the sub-heads for the } \\
\text { payment of school fees will enhance goal achievement. }\end{array}$ & 0 & 0 & 26 & 100 & 36 & 100 \\
\hline & Total & 12 & 5.56 & 204 & 94.44 & 216 & 100 \\
\hline
\end{tabular}

\begin{tabular}{|c|c|c|c|c|c|c|c|}
\hline \multirow{3}{*}{$\mathbf{S} / \mathbf{N}$} & \multicolumn{7}{|l|}{ Table 2b $\quad$ Students Union Executives. } \\
\hline & Questionnaire Items & & & & gree & To & \\
\hline & & No & $\%$ & No & $\%$ & No & $\%$ \\
\hline 1 & $\begin{array}{l}\text { Students' involvement in decision-making on the amount of fees to } \\
\text { pay is a factor in goal achievement. }\end{array}$ & 55 & 62.5 & 33 & 37.5 & 88 & $\begin{array}{l}10 \\
0\end{array}$ \\
\hline 2 & $\begin{array}{l}\text { Students' involvement in decision-making on the mode of school } \\
\text { fees payment will bring about goal achievement. }\end{array}$ & 76 & 86.36 & 12 & 13.64 & 88 & $\begin{array}{l}10 \\
0\end{array}$ \\
\hline 3 & $\begin{array}{l}\text { Students' involvement in making decisions on the time frame for } \\
\text { payment of school fees will contribute to goal achievement. }\end{array}$ & 76 & 86.36 & 12 & 13.64 & 88 & $\begin{array}{l}10 \\
0\end{array}$ \\
\hline
\end{tabular}




\begin{tabular}{|c|c|c|c|c|c|c|c|}
\hline 4 & $\begin{array}{l}\text { Students' participation in making decisions on hostel accommodation } \\
\text { fees will facilitate goal achievement. }\end{array}$ & 55 & 62.5 & 33 & 37.5 & 88 & $\begin{array}{l}10 \\
0\end{array}$ \\
\hline 5 & $\begin{array}{l}\text { Students' involvement in taking decisions on the choice of banks for } \\
\text { payment of school fees will contribute to goal achievement. }\end{array}$ & 76 & 86.36 & 12 & 13.64 & 88 & $\begin{array}{l}10 \\
0\end{array}$ \\
\hline 6 & $\begin{array}{l}\text { Students' participation in making decisions on the sub-heads for the } \\
\text { payment of school fees will enhance goal achievement. }\end{array}$ & 70 & 79.55 & 18 & 20.45 & 88 & $\begin{array}{l}10 \\
0\end{array}$ \\
\hline & Total & 408 & 77.27 & $\begin{array}{l}12 \\
0\end{array}$ & 22.73 & $\begin{array}{l}52 \\
8\end{array}$ & $\begin{array}{l}10 \\
0\end{array}$ \\
\hline
\end{tabular}

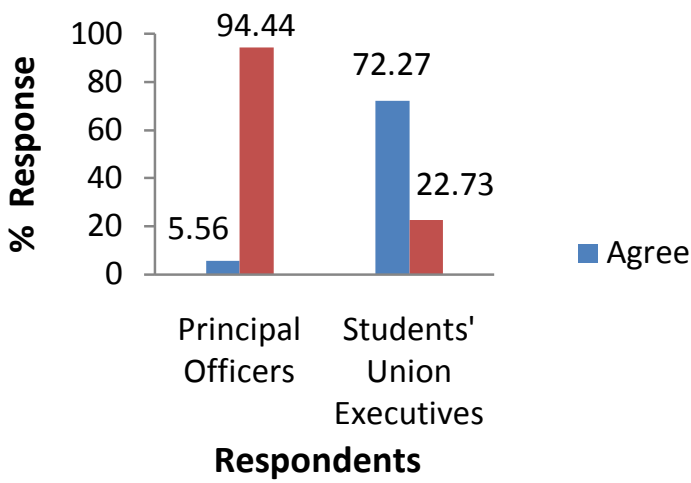

Fig. 1 Perceptions of Principal Officers and Students' Union Executives on Student's Participation in Decision-making on School Fees Matters on Goal Achievements

Table 3: Chi-square Analysis of the Responses of Principal Officers and Students' Union Executives on Students' Participation in Decision-making on School Fees Matters and Goal Achievement Item

\begin{tabular}{|c|c|c|c|}
\hline Principal Officers & Agree & Disagree & Total \\
\hline $\begin{array}{l}\text { Students' participation in Deci } \\
\text { amount of school fees }\end{array}$ & $6(2)$ & $30(34)$ & 36 \\
\hline Mode of payment & 1(2) & $35(34)$ & 36 \\
\hline Time frame of fees payment & $0(2)$ & $36(34)$ & 36 \\
\hline Hostel accommodation fees & $5(2)$ & $31(34)$ & 36 \\
\hline Choice of bank for fees payment & $0(2)$ & $36(34)$ & 36 \\
\hline Sub-heads for fees payment & $0(2)$ & $36(34)$ & 36 \\
\hline Sub-total & 12 & 204 & 216 \\
\hline \multicolumn{4}{|l|}{ Students' Union Executives } \\
\hline Amount of school fees & $55(68)$ & $33(20)$ & 88 \\
\hline Mode of payment & $76(68)$ & $12(20)$ & 88 \\
\hline Time frame of fees payment & $76(68)$ & $12(20)$ & 88 \\
\hline Hostel accommodation & $55(68)$ & $33(20)$ & 88 \\
\hline Choice of bank for fees payment & $76(68)$ & $12(20)$ & 88 \\
\hline Sub-heads for fees payment & $70(68)$ & $18(20)$ & 88 \\
\hline Sub-total & 408 & 120 & 528 \\
\hline $\begin{array}{l}1 \text { Officers } \\
=20.12 \\
\mathrm{a}=9.24\end{array}$ & \multicolumn{3}{|c|}{$\begin{array}{r}\text { Students' Union E } \\
\mathrm{X}^{2} \mathrm{Cal}= \\
\mathrm{X}^{2} \text { critical }=9.24 \\
\text { d.f }=5 \\
\alpha=0.05\end{array}$} \\
\hline
\end{tabular}

Table 3 shows the chi-square calculated values of 20.12 and 34.56 for Principal Officers and Students Union Executives respectively, which are greater than chi-square critical value of 9.24 at 0.05 level of significance and degree of freedom of 5. These, however, show a significant difference in the responses of the two groups of respondents but affirm the need for students' participation in decision-making on school fees related issues.

\section{Conclusion}

The views of Principal Officers and Students' Union Executives on students participation in decisionmaking on school fees matters for goal achievement in 9 Universities in South Eastern Nigeria has been investigated and discussed. The results show a greater desire by the students' leaders to be involved in decision- 
making on school fees matters while the Principal Officers have a contrary view. This explains the reason for students protest and demonstrations each time school fees is reviewed upwardly among these institutions. However, the chi-square values from responses of both groups support students' participation in decisionmaking.

The researcher recommends that students' leaders be adequately involved in making decisions especially in school fees matters so as to be assured of their compliance during implementation. This will invariably enhance peaceful environment needed for personal goal of the students and that of their institutions.

\section{References}

[1]. Babalola, J. B., Adedeji,S.O. (2003) eds. Contemporary Issues in Educational Management.

[2]. Book of Honour, Ibadan: Department of Educational Management, University of Ibadan.

[3]. Boon, A. (2005). Centralization Versus Decentralization and Students Participation Rector's Office + Educational Policy Unit. Retrieved from www.unig.hr/bopro/actovotoes/croatia-student\%20participation.ppt-- on 20/10/2009

[4]. Cole, G. A. (2005). Personnel and Human Resources Management. Fifth Edition, London: Book Power/ELST

[5]. Dimitri, T. (2005) Student participation in University Administration View Public Profile, Visit Dimitri Terryn's Homepage 06.03.05, 071. Retrieved on 8/12/2008

[6]. Enoh, A. O., Bamanja, B. B. and Onwuka,R.O. (1987). A Handbook of Educational Foundations. Jos: Challenge Press.

[7]. Kaye, B. (1970). Participation in Learning. London: George Allen and Urwic Ltd

[8]. Likert, R. (1971). New Patterns of Management. Koga Kusha; McGraw-Hill Ltd.

[9]. Obondoh, A. (2000). Politics of Participatory Decision-making in Campus Governance [10] Kenya: University of Nairobi. Retrieved from www.ifra-nairobi.net/cahiers/Kenya-19/Kobondo.pdf on 05/09/2009

[10]. Ojo, J. D. (1995). Students' Unrest in Nigerian Universities. A Legal and Historical Approach. Ibadan: Spectrum Books Ltd.

[11]. Okorie, F. U (2012) Students' Participation in Decision-making as a Factor of Goal Achievement in Universities is the South Eastern States of Nigeria. Unpublished PhD Thesis, Abia State University, Uturu.

[12]. Olaniyan, D. A. and Okemakinde, T. in Babalola J. B. and Adedeji, S. O. eds. (2003).Contemporary issues in Educational Management. A Book of Honour Ibadan: University of Ibadan.

[13]. Richter, F.D and Tjosvold, D. (2011). Effects of Student Participation in Classroom Decision-Making on Attitudes, Peer Interaction, Motivation and Learning. Journal of Applied Psychology, Vol. 65(1). Retrieved from http://psycnet.apa.org/journalsapl/65/1/74/on $11 / 8 / 2011$.

[14]. Uyanga, R. E. (1989). Educational Administration and Planning. A Collaborative Approach, Lagos: Agege Press.

[15]. Wyn, R. (1979). Training Administrators and Development. London: Heinemann. 